\title{
Transformation of corporate governance in the Russia's electric power industry
}

\author{
Galina I. Sheveleva* \\ Melentiev Energy Systems Institute, Siberian Branch of the Russian Academy of Sciences, Irkutsk, Russia
}

\begin{abstract}
To make Russia' electric power industry more appealing for investors, in the course of its reformation its generating assets were privatized with international corporate governance principles adopted. One of the key reasons that hinder the solution of the above problem is the transformation of corporate governance. The results of the assessment of power generating companies' compliance with the Corporate Governance Code in 2017-2018 are presented. The assessment was conducted using the Bank of Russia methodology. An additional analysis of information on general corporate governance practices as retrieved from the official websites of these companies was performed. We took into account the findings of the research published in this area as carried out at St. Petersburg State University, the New Economic School, the Russian Institute of Directors, the Platforma Center for Social Engineering, the MGIMO University, the Independent Directors Association and the HSE University. The key aspects of corporate governance transformation in the Russia's electric power industry were identified by summarizing the data thus obtained. They were primarily limited to claiming a formal approach adopted by majority owners so as to comply with international corporate governance standards in the process of permanent redistribution of ownership and increasing its concentration.
\end{abstract}

\section{Introduction}

Creating prerequisites for attracting investments was one of the key tasks behind reforming the Russia's electric power industry back in 2003-2008. To this end, its generating assets were privatized and the foundations for corporate governance were laid down in accordance with international standards. However, the problem of increasing investment appeal of wholesale and territorial power generating companies (WGCs and TGCs, hereinafter referred to as generating companies) by improving corporate governance was not solved.

The purpose of the study of current corporate governance practices in these companies was to identify the key points of its transformation that hinder the solution of the problem of attracting investments.

The corporate governance transformation was determined primarily on the basis of the data obtained on ownership redistribution in generating companies and assessment of their compliance with the principles set out in the Russian Corporate Governance Code (the updated version of 2014, hereinafter the Code) [1]. The provisions of the Code are based on the international practice in the sphere of corporate governance, internationally recognized principles of corporate governance developed by the Organization for Economic Cooperation and Development (OECD) [2].

The research methodology is mainly based on the recommendations of the Bank of Russia to be followed by companies when compiling reports "On Compliance with the Principles and Guidelines of the Corporate Governance Code" (Letter of the Bank of Russia dated February 17, 2016 No. IN-06-52/8) [3].

We studied the generating companies that disclosed Annexes "On Compliance with the Principles and Guidelines of the Corporate Governance Code" as part of their annual reports for years 2017 to 2018 (Inter RAO PJSC, Enel Russia PJSC, RusHydro PJSC, WGC-2 PJSC, Unipro PJSC, TGC-1 PJSC, TGC-2 OJSC, Mosenergo PJSC, Quadra PJSC, T Plus PJSC, TGC-14 PJSC, and Irkutskenergo PJSC). Omitted from our consideration were Siberian Generating Company LLC and generating companies of LUKOIL PJSC that did not post such reports on their official websites, as well as Fortum OJSC whose report failed to comply with guidelines of the Bank of Russia. The study covers Irkutskenergo PJSC (now EuroSibEnergo JSC), originally not a part of a WGC and TGC.

The following data sources were used: official websites of generating companies (including the list and content of internal documents, governing bodies, annual and quarterly reports); St. Petersburg State University [4]; author's published research in this field [5-7]; New Economic School [8]; Russian Institute of Directors [9]; the "Platforma" Centre for Social Engineering [10]; the Centre for Strategic Studies at the MGIMO University [11]; Association of Independent Directors and National Research University Higher School of Economics (HSE University) [12]; news agencies and other Internet resources [13-17].

* Corresponding author: sheveleva@isem.irk.ru 


\section{Redistribution and concentration of ownership}

Generating assets structure and, accordingly, ownership of Russian generating companies after liquidation in 2008 of RAO UES PJSC was constantly changing. Many of the industry assets were renamed. Ownership was redistributed between the state, foreign and domestic private owners, as well as within each of these groups.

The analysis of data from the generating companies' official websites on the main shareholders and their shares in the capital stock at the end of 2019 showed an increase in ownership concentration and government presence. The state-owned company Inter RAO PJSC acquired $100 \%$ of voting shares of TGC-11 JSC, reorganized WGC-1 OJSC and WGC-3 OJSC with respect to its $100 \%$ ownership of shares there and incorporated Bashkirenergo OJSC. WGC-2 OJSC and WGC-6 OJSC were subsumed by Gazprom Energoholding LLC. Negotiations are underway to merge T Plus PJSC, part of the Renova Group, with Gazprom Energoholding, owned by V. Vekselberg [13].

The increase in ownership concentration was observed not only in state-owned companies, but also in companies with foreign and private Russian owners. In particular, in Unipro PJSC (formerly WGC-4 OJSC) it increased from $78.1 \%$ (2009) to $83.7 \%$ (2019). Fortum OJSC (formerly TGC-10 OJSC) increased its share in the capital stock of this company from $92.9 \%$ (2009) to $98.3 \%$ (2019). The share of Russian entrepreneurs increased. TGC-12 OJSC and TGC-13 OJSC were merged into the Siberian Generating Company Group. TGC-7 OJSC (Volga TGC) was renamed into T Plus PJSC in 2015 after having TGC-5, TGC-6, and TGC-9 joined it.

In fact, the level of ownership concentration in generating companies is even higher than is reported in official statistics. This is mainly due to the ownership of shares of these companies by the entities controlled by the majority shareholders or by the entities affiliated with them, which ensure that they maintain actual control over these companies.

In particular, Centrenergoholding OJSC is a subsidiary of Gazprom Energoholding LLC; Gazprom Energoholding LLC is a $100 \%$ subsidiary of Gazprom PJSC; Energopromsbyt is a subsidiary of Russian Railways OJSC. TGC-2 OJSC's majority shareholder is Sintez Group. It is owned by a Russian entrepreneur L. Lebedev. The same Group exercises control over Kores Invest LLC, foreign offshore companies Janan Holdings Limited, Raltaka Enterprises Ltd., and Litim Trading Limited. According to the Unified State Register of Legal Entities, the founder of Debt Agency LLC is TGC2 OJSC as well. Mr. M. Prokhorov controls the main shareholders of Quadra PJSC that is ONEXIM Group LLC and Business INFORM LLC [14].

Such an increase in ownership concentration in generating companies was often accompanied by dishonest conduct of majority owners. They "diluted" minority shareholders' blocks of shares by placing additional issues repurchased then by their affiliated entities and forced minority shareholders to sell their shares at prices significantly below their initial offering [7].

According to calculations made on the basis of data from the official websites of these companies, at the beginning of 2020 the state controlled $63.9 \%$ of the installed electric power capacity of wholesale and territorial generating companies of the electric power industry, with private entrepreneurs owning $22.47 \%$, and foreign owners owning $13.63 \%$.

The permanent redistribution and increased concentration of ownership in generating companies eventually led to the transformation of their corporate governance.

\section{Transformation of corporate governance}

A sui generis indicator of corporate governance implementation in generating companies is their compliance with the principles of the Code of Corporate Governance (hereinafter, the Code principles). The sustainability and efficiency of their activities and the increase in the inflow of investments from domestic sources and from foreign investors depend on compliance with these principles. The higher the level of protection of shareholders' interests, regardless of the size of the shareholding, companies will be able to achieve, the more investment they will be able to count on [1].

\subsection{Compliance with the Code principles}

The analysis of generating companies' compliance with the Code's principles was primarily performed based on their reports "On Compliance with the Principles and Guidelines of the Corporate Governance Code" in their annual reports.

This analysis was performed based on 128 criteria for the assessment of generating companies' compliance in 2017-2018 with 79 Code principles recommended by the Bank of Russia (hereinafter referred to as the Code criteria), as grouped by compliance status ("complied with", "partially complied with", "not complied with").

Significant differences in compliance of these companies with the Code criteria were noted. In terms of compliance with them, the leaders in 2018 were stateowned companies Inter RAO PJSC, RusHydro PJSC, and Enel Russia PJSC (Italy). Out of 128 criteria they complied with 125,123 , and 120 criteria, respectively. The outsider companies that ranked at the bottom of the list with 58 and 38 criteria of compliance and had Russian private owners were TGC-2 PJSC and Irkutskenergo PJSC, respectively. When comparing the values of the "not complied with" status as applied to the leading and outsider companies, we observed virtually the same correlation, but with a more significant gap between the values. Inter RAO PJSC failed to comply with 1 criterion, while Enel Russia PJSC and RusHydro PJSC failed to comply with 3 ones. Irkutskenergo PJSC, Quadra PJSC, and TGC-2 PJSC lagged behind Inter RAO PJSC by 27-33 times with respect to their compliance. 
No less significant differences in the status of compliance with the Code principles were identified within these companies themselves. In the leading companies in 2018 among 128 evaluated criteria the share of components of the compliance status components were as follows: Inter RAO PJSC - 97.6\%, $1.6 \%$, and $0.8 \%$; Enel Russia PJSC - 93.8\%, 3.9\%, and $2.3 \%$; RusHydro PJSC - 96.1\%, $1.6 \%$, and $2.3 \%$. Outsider companies saw a relative upward shift in the criteria for those "partially complied with" and "not complied with": Irkutskenergo PJSC - 29.7\%, 49.2\%, 21.1\%; Quadra PJSC - 58.6\%, 17.2\%, 24.2\%; TGC-2 PJSC $-45.3 \%, 28.9 \%, 25.8 \%$.

When comparing compliance with the Code criteria in 2017 and 2018, there were bidirectional trends in generating companies. The leading companies, as well as Unipro PJSC and Quadra PJSC, on average, increased the number of criteria they comply with by $11-12 \%$, while the rest of the companies reduced them, and in TGC-1 PJSC and Irkutskenergo PJSC it was almost by the same number. The share of criteria the that outsider companies failed to comply with increased from $14.8 \%$ to $21.1 \%$ at Irkutskenergo PJSC and from $22.7 \%$ to $25.8 \%$ at TGC-2 PJSC. The number of the criteria Mosenergo PJSC, Irkutskenergo PJSC, and TGC-1 PJSC "partially comply with" increased.

The transformation of corporate governance was primarily revealed through an analysis of mandatory explanations on the reasons for non-compliance provided by generating companies in their reports "On Compliance with the Principles and Guidelines of the Corporate Governance Code", as well as an analysis of generalized data on corporate governance practices from their official websites. "Comply or explain" is an element of so-called international "soft regulations" recommended for countries with relatively weak legal and regulatory structures [2].

\subsection{Compliance with international "soft regulation"}

Below are the most telling explanations of the reasons why the overwhelming majority of generating companies failed to comply with the Code criteria, indicating the formal approach of majority owners to compliance with international corporate governance principles.

The most common explanations were combined into two groups. The first one is "not foreseen, conducted, considered, defined, etc.", the second one is "the company plans to consider the possibility of including, conducting, adopting, etc.". These formulations are exemplified by compliance with principles 7.1.1., 7.1.2. and 7.2.2. of the section on material corporate actions (VII): 7.1.1. The list of transactions or other actions that are material corporate actions and criteria for defining them are not defined; 7.1.2. There is no procedure set out for independent directors to state their opinions on material corporate actions prior to their approval; 7.2.2. The Company plans to consider the issue of incorporating in its internal documents an extended list of grounds on which members of the Company's Board of Directors and other persons provided for by law are deemed interested in its transactions. The use of such typical explanations by generating companies for at least several years indicates that their boards of directors did not respond in a timely manner to compliance with the Code principles or that there was a latent reluctance to comply with them and to update internal documents [5].

No less formal are the most common explanations for non-compliance with Principle 6.1.1. of the Code (development and implementation of information policy in companies): 1. "...the information policy was developed and approved, however, in the reporting period the issues related to its compliance were not considered due to compliance with the requirements of the current legislation and internal documents of the companies"; 2. "...the information policy was approved prior to the Code development and does not take into account the recommendations introduced by the Code". It follows from these explanations that the boards of directors did not fulfill their most basic duties to control the information policy of generating companies. Besides, the explanation stating that "...information policy mostly meets the requirements of the company's internal documents", when the generating companies do not update these documents, fail to appear convincing in the least. The lack of such updates is evidenced by the results of an additional analysis of the list and content of generating companies' internal documents, including the years of approval of their "Information Policy Regulations". In particular, it is 2006 in TGC-2 PJSC and Quadra PJSC, 2008 - in TGC-1 PJSC, 2009 - in WGC-2 PJSC, and 2011 - in Irkutskenergo PJSC.

It is possible that controlling shareholders, by giving such explanations, conceal concerns about serious risks of disclosure of material information about their companies' activities, outweighing possible benefits.

Explanations for a failure to comply with Principles 2.4.3 (presence of a certain minimum number of independent directors on the boards of directors) and 2.5.1 (independence of the chairman of the board of directors or determination of the senior independent director) prove formal as they relate to a lack of objective possibility to influence the election process of the board of directors members. In fact, the composition of boards of directors and the appointment of their chairs are made on the recommendation of the controlling shareholder, and voting is a pure formality. For example, in Quadra PJSC, for several years now the board of directors has been formed by the controlling shareholder Mr. M. Prokhorov ( 8 out of 9 members), and there are no plans to change the existing practice prior to his changing this approach.

This is also true for state-owned companies that have reported on compliance with these principles. In particular, RusHydro PJSC has 11 out of 13 members of its board of directors appointed by the government [1517]. In violation of the Code, the company's independent directors are affiliated with a substantial shareholder, i.e. the state. For example, A.O. Chekunkov is the executive director of Foundation for the Development of the Far East and the Arctic JSC, which is part of a unified system of state institutions for the accelerated development of the Far East and the Arctic [15].

A certain correlation was detected between the data obtained herein and the findings of the research 
published in this area as carried out at St. Petersburg State University, the New Economic School, the Russian Institute of Directors, the Platforma Centre for Social Engineering, the Centre for Strategic Studies at the MGIMO University, the Independent Directors Association and the HSE University. It mostly boiled down to the gap between the relatively developed regulatory and legal framework for domestic corporate governance (including the Code) and the realities of Russian corporate practices: full control of majority shareholders over companies and formal compliance with the international principles incorporated into that framework [4, 8-12].

\section{Conclusion}

In the process of reforming Russia's electric power industry, the improvement of corporate governance was viewed as one of the most important factors contributing to its investment appeal. In order to determine its transformation that hinders the solution of this problem, an analysis of corporate practices established in generating companies in 2017-2018 was performed. It was conducted primarily based on the Bank of Russia methodology recommended for Russian companies when compiling their reports "On Compliance with the Principles and Guidelines of the Corporate Governance Code".

The key points of corporate governance transformation in generating companies were identified. They included an increase in ownership and power concentration among majority owners and a formal approach to compliance with international corporate governance principles underlying Russian corporate law. Such transformation of corporate governance in these companies has a negative impact on their investment appeal.

The research is conducted in the framework of scientific project № AAAA-A17-117030310438-1 of the program of fundamental research of SB RAS III.17.4.

\section{References}

1. Corporate Governance Code. Regulations and up-todate information of the Central Bank of the Russian Federation, Vestnik Banka Rossii, 40 (2014) (in Russian)

2. OECD. Principles of corporate governance. G20/OECD Publishing, Paris (2016). [Online]. Available: http://dx.doi.org/10.1787/9789264252035-ru

3. Bank of Russia Information Letter No. IN-06-52/8 (2016). [Online]. Available: https://www.garant.ru/products/ipo/prime/doc/71237 796/ (in Russian)

4. A.V. Bukhvalov, Rossijskij zhurnal menedzhmenta, Vol. 3, No. 3, 81 (2005) (in Russian)

5. Galina I. Sheveleva, Implementation of international standards of corporate governance in Russian electric power industry // Energy Systems Research,
Vol. 1, No. 3, $33 \quad$ (2018) DOI: http://dx.doi.org/10.25729/esr.2018.01.0001

6. Galina I. Sheveleva, Priority directions in the development of corporate governance in Russia's power industry // Energy Systems Research, Vol. 2, No. 3, 5 (2019) DOI: http://dx.doi.org/10.25729/esr.2019.03.0001

7. N.I. Voropai, et al., Justification of power system expansion: methodology, models, methods, and their application (Nauka, Novosibirsk, 2015) (in Russian)

8. S.M. Guriev, Myths of economics. Fallacies and stereotypes disseminated by mass media and politicians (Mann, Ivanov, and Ferber, Moscow, 2017) (in Russian)

9. I. Belikov, Board of directors: a new approach (RIPOL Classic, Moscow, 2019) (in Russian)

10. Corporate Governance in Russia: Genre identity crisis and hopes for the future ("Platforma" Centre for Social Engineering, Moscow, 2018). [Online]. Available:

http://www.nand.ru/upload/medialibrary/news (in Russian)

11. E.B. Zavyalova, V.B. Kondratiev, Corporate governance as a factor to increase investment appeal (MGIMO University, Moscow, 2014) (in Russian)

12. Corporate governance index of Russia (2017). [Online]. Available: http://nand.ru/upload/ux/corporate_governance_inde x_2017.pdf (in Russian)

13. Vekselberg confirms talks on $\mathrm{T}$ Plus and Gazprom Energoholding merging the assets. [Online]. Available:

http://www.bigpowernews.ru/print/83095/phtml (in Russian)

14. Quarterly report of Quadra PJSC for Q3 (2019). [Online].

Available: https:/www.quadra.ru/upload/iblock/b48/b48217d5 91d17de9138aca2faa6270ee.pdf (in Russian)

15. Foundation for the Development of the Far East and the Arctic. [Online]. Available: https://www.fondvostok.ru/about/ (in Russian)

16. Decree of the Government of the Russian Federation No. 1393-r On Establishment of an Autonomous Nonprofit Organization "Agency for Strategic Initiatives to Promote New Projects" (2011). [Online]. Available: http:/goverment.ru/gov/results/16183/ (in Russian)

17. Nonprofit partnership "Scientific and technical council of the Unified Energy System". [Online]. Available: http://www.nts-ees.ru/ (in Russian) 